University of Louisville

ThinkIR: The University of Louisville's Institutional Repository

College of Arts \& Sciences Senior Honors

Theses

College of Arts \& Sciences

$5-2015$

\title{
An act of creation : solo storytelling of Greek mythology.
}

James Thompson

University of Louisville

Follow this and additional works at: https://ir.library.louisville.edu/honors

Part of the Theatre and Performance Studies Commons

\section{Recommended Citation}

Thompson, James, "An act of creation : solo storytelling of Greek mythology." (2015). College of Arts \& Sciences Senior Honors Theses. Paper 31.

http://doi.org/10.18297/honors/31

This Senior Honors Thesis is brought to you for free and open access by the College of Arts \& Sciences at ThinkIR: The University of Louisville's Institutional Repository. It has been accepted for inclusion in College of Arts \& Sciences Senior Honors Theses by an authorized administrator of ThinkIR: The University of Louisville's Institutional Repository. This title appears here courtesy of the author, who has retained all other copyrights. For more information, please contact thinkir@louisville.edu. 


\title{
An Act of Creation:
}

\section{Solo Storytelling of Greek Mythology}

\author{
By \\ James Thompson
}

Submitted in partial fulfillment of the requirements

for Graduation summa cum laude

and

for Graduation with Honors from the Department of Theatre Arts

University of Louisville

March, 2015 


\section{Introduction}

In the theatre of American realism, particularly in when performed in an academic setting, there are often clear hierarchical power relationships established between the different creative components involved in the production of a show. If viewed as a model of a society, the power dynamics instituted take on familiar points of reference: the playwright becomes the godfigure, whose word is sacred and cannot be challenged or changed. The director, then, is a monarch, ruling the societal microcosm by divine right, granted to him or her via purchasing the rights to produce the play. Therefore the actors, designers, and stagehands contracted to fulfill the director's vision can be treated as serfs, powerless and subservient to their masters despite doing the actual work. The society on which this type of theatre is modeled bears resemblance to the feudal systems of the Middle Ages, or, more similar than Americans may care to admit, to the United States' prominent capitalist exploitation of the many for the financial benefit of the few. Examined under this light, the rehearsal room frequently becomes a nation ruled by dictatorship, where the actors' creative input can easily be suppressed or wholly disregarded should a director be inclined to abuse the absolutist power that is usually implied by that position.

Even before the director's rise to prominence, theatre had consisted of a relationship between playwright and actor for 2000 years, back to ancient Greece during the days of Aeschylus and Sophocles (Bartow xvii). Even in that situation, the actor remained powerless against the playwright and had no choice but to submit and perform what and how he was commanded. This process of using actors as tools is an intrinsic part of American theatre - the first American school established for actor training, in 1884 by Steele MacKaye, was created because MacKaye, a director and playwright, wanted to train his own company of actors in a 
uniform way so that he could use them to produce the kind of theatre in which he was interested (xviii). No regard was given to the actors themselves; he simply needed the bodies taught how to work for his own interests.

This view of the actor as a mere instrument that can be manipulated for one's purposes has persisted to today, as recently as 2014 at the University of Louisville. In her Master's thesis, Ashley Smith writes about her dissatisfaction in being directed how to perform the role of Ariel in Shakespeare's The Tempest in the University of Louisville's Theatre Arts department's 201314 season: the director told her that she was acting "too much like a girl" (28). She was then instructed to portray the non-human spirit character as "non-gendered" (31). Smith was frustrated by this direction as it not only added a new layer of difficulty to an already challenging role, she also simply did not want to explore the idea of genderlessness in this role (29). Unfortunately, she did not have a choice in the matter and had to submit to these new restrictions placed on her by the person in charge.

This is a struggle faced by all actors striving to overturn and escape from a potentially oppressive system. American theatres often may not showcase a great variety of styles; in fact the only two styles in which I was trained for the majority of my university-level acting classes were American realism and Shakespearean acting. This limited range is a good representation of the different types of non-musical theatre to which American theatre-goers have been exposed. The dominant form of commercial theatre in America seems to dictate how an actor must work in order to be successful and make a living, namely through American realism or musical theatre. This has created the impression that actors must be trained in and take on these particular styles in order to be regularly employed in the mainstream market. As a result, the number of actors willing to step outside of those styles has diminished. This is limiting the opportunity for growth 
and change - if American realism is all we practice, then American realism is all our theatre will ever be. Through the exploration of new styles of theatre that place creative power in the actor's hands, the essence of American theatre can evolve from an art based on just money into an art focused on true creativity and community engagement through that art. This is so important to theatre as a whole by developing a new way to get audiences invested in theatrical works in a time when Hollywood films have taken over the as the high point of entertainment which was once filled by theatre.

Other scholars have tackled the questions surrounding the possibility of the actor behaving as a creative entity. Derek S. Mudd describes, in his contribution to The Politics of American Actor Training, two situations in two different MFA programs, ten years apart, in which his input and character research were wholly disregarded and he himself abused by acting coaches intent to force their own interpretations of characters onto his performances. He acknowledges himself as being powerless in those instances, and resolved from then on to become a teacher and "empower student-actors to value themselves as contributors..." (149). However, Mudd's primary interest in collaborative creative efforts is that between artists, leaving the audience entirely out of the equation. This unconscious disregard for the audience, an absolutely integral part of theatrical performance, is an incredibly common practice in theatre today, and one I seek to avoid by interacting directly with my audience and sharing authority in the creative process with them every single night of a performance.

Jodi Kanter, on the other hand, describes in her book, Performing Loss, a process that is wholly focused on engaging the audience through performance. She describes a devised piece performed by college students for hospice patients, in which three students walked into the audience and picked a certain person to tell a true story about an object that strongly reminded 
them of a person, and then invited that audience member to tell a similar story of their own. According to Kanter, this piece received the strongest response from the audience, and became "performance as community dialogue, where the goal is not to give but to exchange, to open up a genuine conversation about a shared experience or concern" (51).

This resonated strongly with me, mirroring the same pursuit I have in engaging with my audience. But Kanter's interests seem to be solely focused on using this dialogue as a way to confront and deal with loss within the community. Rather, I am seeking, through my art, a way to empower both actor and audience with the capacity to create and shape dramatic works that has been denied them by mainstream theatrical practices. While the means which Kanter and I both employ may be similar, our end goals differ in their intent and overall consequences.

As it has occurred countless times throughout human history, those chafing under a disagreeable system have one major recourse at hand: revolution. And, as Spartacus led the slaves in revolt against the Roman Republic, and Che Guevara played a key role in the Cuban Revolution, so did Dario Fo become a driving influence behind the struggle for creative independence in $20^{\text {th }}$ century Italy. Inspired by Fo's work, I recently made a decision that was counter to everything in my development to that point as an artist. I devised an original solo performance based on two ancient Greek myths using Fo's physical storytelling style. While these two myths have existed for thousands of years, I have adapted them for a solo storyteller and made creative decisions about the structure and content of the performance, which the myths themselves support by reflecting my interests in inverting power structures. Through this process, I have discovered that when an actor takes on a creative role, using his or her body instead of only words to create a performance, he or she is able to enter into a direct dialogue with the audience and share the artistic authority over the piece being performed with them. 


\section{The Fo Project}

Dario Fo is a world famous Italian performer, playwright, and Nobel laureate, whose significant stylistic contributions to Italian theatre have formed the basis for the Dario Fo Project, an international collaborative effort based at the Accademia dell'Arte in Arezzo, Italy with the purpose of teaching his specific style of physical storytelling to an international consortium of students, with English as the working language. I participated in the Fo Project in Italy during the summers of 2013 and 2014, and was personally trained by the internationally renowned Italian actor Michele Bottini, a protégé of Fo's. I will be returning in the summer of 2015 to perform at the 2015 World Expo in Milan as part of an international ensemble with the English-language premier of Fo's latest masterpiece, The Story of $Q u$.

I was part of a program that offers the only avenue for this type of training in English, learning from a student of the master himself, and the students then brought Fo's training with us back to our own countries of origin. Fo's style was born of a very specific set of circumstances in the middle of the $20^{\text {th }}$ century after he had lived as a political rebel and deserter in fascist Italy during World War II (Mitchell 49-50). As I perform in his style here in the $21^{\text {st }}$ century United States, what Fo did begins to mean something else. After years of American realism and Shakespeare as the dominant types of theatre at the University of Louisville, Fo's style of storytelling appeared as a pioneering theatrical effort with a purpose, even if the average audience member may not recognize it as inherently resistant.

The Fo Project introduced me to the first non-text based acting style I had ever experienced. As an American student, as I mention above, all of the acting training I had received thus far in my career had been purely academic with a heavy emphasis in realism. In 
almost every acting class I had taken at the University of Louisville, we were taught in the style of Konstantin Stanislavski, a Russian actor and director, whose method for acting was highly naturalistic and greatly influenced the entirety of American drama from the early twentieth century to the present (Bartow xxi). This is one reason so much of American theatre is performed realistically, with an invisible "fourth wall" separating the world of the play from the observing audience. This method involves analyzing a play by exploring the psychology of characters to determine their objectives during the play, in order to "summon lifelike behavior" (xxi).

Italian theatre and its practitioners (Fo included) were not influenced to the same degree by the Stanislavski method, therefore the enduring non-realistic styles of Italian theatre, such as Commedia dell'Arte, continued to exist, grow, and maturate into new theatrical styles, like Fo's storytelling (Mitchell 91-2). Our work in Italy with the Fo Project highlighted the importance of nonverbal communication of plot and themes. We learned to use our bodies, our gestures, our physicality, and a direct and constant relationship with the audience to successfully relay complicated stories to the listeners. Even after all language and words were stripped from us, we spoke in gibberish and used the tones of our voices to support the story, but the main form of communication was completely physical. This act of creating through the body, rather than only words written by someone else, opened up a revolutionary possibility for me, as an American actor, to create my own work without a playwright.

\section{In an American Context}

My experiences in being trained and performing in Fo's style have dramatically changed my creative interests and introduced me to a style of theatre that I both enjoy and am passionate about exploring further. This style is so drastically different from acting in American realism, 
which was derived from Stanislavski's method, that there is almost no room for overlap. The fourth wall that is so vital in realism cannot exist in storytelling; the performer is speaking directly to the audience and making eye contact with them to maintain the communal connection between storyteller and listener. So often in American theatre the audience is left completely out of the conversation, when they are in fact such an integral part of theatre. Storytelling, on the other hand, directly involves the audience in an interaction in which both sides can contribute, rather than taking the stage as an authority figure, giving the audience a presentation to which they must listen simply because "those are the rules of the theatre." When I perform in Fo's style, that may not be the first time someone in my audience has seen a performing actor speak directly to the audience, but a performer actually taking the audience's reactions and changing the show based on that input is something that simply cannot happen in a style of theatre that is wholly focused on the sagacity of the playwright's words.

The possibility of conversation is denied in most American theatre because the actors are not speaking for themselves, they are merely mouthpieces through which the playwright makes their opinions known, given voice by the director. American realism is designed exclusively to deal with plays that have already been written, but Fo's interests deal with the actor-as-creator, where the performer him/herself devises and improvises the story. This aspect of Fo's work, an actor-driven text rather than playwright-driven, is what interests me most about this work - the actor as a creator, rather than as only an interpreter of another's creation.

This has led me to my personal distinction between a playwright and a play writer. The truth is that I am simply not good at writing plays, I made attempts that all ended in failure. But the "-wright" suffix does not mean "writer," it means "maker." I was not able to create dramatic works with a pen and paper, so I cast those aside and became a craftsman, a builder of plays. I 
work through the creative process with my body, physically creating a story, characters, plot, etc. I write down parts that worked well, parts I enjoyed, but there is no script with stage directions for any actor to pick up and use. This creates a performance wholly unique to me that I may change, adapt, shorten, or lengthen as necessary, depending on the feedback I receive from my audience.

\section{World Enough, and Time}

Inspired by my training in Fo's storytelling techniques, I used this process as an opportunity to explore the actor as a creative entity, capable of devising original performances, rather than simply an interpretive one who only performs material that other artists have provided. I have devised, rehearsed, and performed an original theatrical performance, entitled World Enough, and Time (taken from the first line of Andrew Marvell's poem, To His Coy Mistress), by taking two of the Greek myths from my childhood copy of d'Aulaire's Book of Greek Myths: "Orpheus and Eurydice" (about a man who travels to the underworld to bring back his dead wife), and "Echo and Narcissus" (about a nymph whose punishment for her incessant chatter is the loss of her ability to speak except for repeating the words of others); and telling them to an audience using Fo's physical storytelling techniques.

These myths relate very well to the questions I seek to answer as an artist- how can the artist act as a sort of Orphic deliverer, delving to the depths of the "underworld" - another realm, whether it be the imagination, the annals of history, or the depths of the mind through psychology - through his or her art to bring back some sort of truth or understanding to share with the public? How does one deal with the loss of language and negotiate a social existence without the ability to speak or be understood through language? 
These two questions are ones I eagerly wished to explore, but under my previous restrictions that would have been next to impossible, lacking a director, budget, or even a play that addressed these issues in the way I wanted to approach them. American realism would have required material resources that I as a college student (and possibly most professional actors) was in no position to access. This is shown in Lorrain Hansberry's 1959 play, A Raisin in the Sun, a classic example of the wonders of American realism. Hansberry's script not only requires a full kitchen to be constructed on stage, but it must also be functional as one character cooks scrambled eggs on stage during the first scene (24-6). This level of realism requires money, space, and a full production staff to put together, none of which I possessed. However, after my training in Italy, I was equipped with the skills necessary to create my own performance and focus on my own interests.

Besides the influence from having a solid base of training in this particular style, several other factors led to my final decision. There is a possible historical perspective, as I discovered Fo's style seemed well suited to my piece as a contribution to the lineage of the aoidoi, ancient Greek bards that traveled from city to city and were likely responsible for the survival of these myths before the advent of written language (Nagy 43). It is relevant to note the distinction between an ancient Greek aoidos and a rhapsoidos, which were both oral poets relating the classic tales to audiences, but who functioned differently.

A rhapsoidos was more similar to the typical American actor who performs in written plays, speaking memorized lines. These poets recited poems of great writers, such as Homer and Hesiod, to Greek audiences while they were already congregated for events or festivals, and to improvise on the works of those great poets was inexcusable. Aoidoi, however, seem to be the artistic ancestors of Fo and the giullari - the medieval minstrels who would tour through Italian 
cities, performing for the common folk on whom Fo based his style (Brockett 427). Aoidoi were true oral poets, speaking their own work to local audiences, traveling through different cities throughout the Greek world. While not considered truly "creative," as their poems were born from classic tales and traditional values of the time, aoidoi are part of an artistic lineage of performers who have acted on the opportunity to create their own art (Nagy 42-3). While my renditions of these classical myths are no doubt vastly different from the ancient bards', I found an echo of authenticity in rehearsals because of my method of solo storytelling. I am aware of the historical continuum into which my work fits, but while it is an exciting avenue for future research, it is beyond the scope of this paper.

So, more significantly, I decided on this style of performance because it is a piece that I can create as an actor, rather than a writer. Fo himself wrote several plays, which helped earn him the 1997 Nobel Prize in Literature, but I consider his most powerful and interesting work to be in the style that I am trying to emulate because of the simultaneous freedom and control it grants the artist. Rather than sitting hunched over a computer typing out endless lines of dialogue and stage directions, I am up on my feet actively performing the entire time. Much of this work is based on improvisation; therefore I am creating my entire performance anew every time I step onto the stage, depending on how my audience responds. I can try out new ideas as they come to me and decide if they work or not as I share them with an audience. This process has turned me into an active actor and artist, and renders my piece as constantly evolving and maturing, so that it will never grow stale - there will be something new for me to discover every time I perform it for a new and different audience.

In developing my performance project, I felt like a true artist for the first time. Previously as an actor, that spark of ownership over my work was absent. In my work interpreting a pre- 
written role in a play, I was more like the painters who make their money by reproducing works by masters like Caravaggio or Rembrandt - they are still exceptionally skilled, but have no creative ownership over their pieces, all their hard work only contributes to the original painter's fame, rather than establishing their own body of work based on their own creative talents. No matter how renowned an actor may become in the world of theatre, they will simply be playing a part in someone else's masterpiece.

After thorough exploration of the creative process by devising an original theatrical performance, I have learned that the purpose of an actor is not limited to obedience - to moving and speaking exactly as instructed. Rather, an actor has the capacity to assert his or her artistic perspective through creative constructs and become a fully realized, meaning-making entity in his or her own right. However, sharing the authority to produce these performances collaboratively with an audience creates an open forum that empowers the collective community, rather than placing one performer or playwright's voice above the rest. This method of actoraudience communication is what excites me the most about Fo's work. 


\section{Chapter One: The Political Clown}

Dario Fo is an actor, playwright, director, comedian, political activist, and "arguably the most widely performed contemporary playwright in world theatre" (Mitchell xiii). His strong leftist political beliefs have colored much of his dramatic work throughout his career, from a short sketch about the United States' racist Jim Crow laws in the early 1950's (54) to his most recent masterpiece, The Story of $Q u$, dealing with the rise of communism in China. Fo has combated social problems and injustice through his art, such as We Can't Pay! We Won't Pay! in 1974, featuring women forced to steal food due to the gross inflation present in Italy during the 70s (130), and Accidental Death of an Anarchist, in 1970, based on the true events of an anarchist who died in police custody under suspicious circumstances (101).

Considered by many to be a "political clown" (Jenkins 242), Fo has been creating theatre for over six decades that has critiqued everything from inflation to fascism to the Roman Catholic Church. In fact, Mistero Buffo, which is considered one of Fo's greatest works, in which he comically retells apocryphal tales not included in the Christian Bible, was branded by the Vatican to be "the most blasphemous show in the history of television" (Mitchell 3). Mistero Buffo was the basis for the majority of my training in Fo's storytelling techniques during the first session of the Fo Project. Participants selected a story to tell and worked with Bottini and Italian students from the Paolo Grassi School in Milan to develop the necessary skills for this type of performance. The two summers of training in this style I received have been invaluable to this project, having allowed me to begin work with a solid base of experience in the work. Fo's style is not only very different from the kind of theatre in which I had previously trained, but is itself difficult to learn and practice on one's own. 
Fo's storytelling style is inherently resistant; he rejects the bourgeois elements of theatre - the grand sets, elaborate costumes - and instead utilizes just the tools available to anyone: his voice, body, and imagination. Actors, who are innately associated with the body, act as the laborers in service to the intellectual director. However, this system can be overturned by the simple epiphany that it is the actors themselves doing the work, their labor is absolutely vital to the project's existence, which may lead them to question why they remain in the subservient class. In the same vein, the audience is an integral part of theatre, but they are frequently paid no attention in a performance aside from a bit of direct-audience address.

The biggest lesson imparted to us that first summer was the paramount importance of fostering a connection to the audience. In Fo's work, the storyteller must maintain near-constant eye contact with the audience (Jenkins 248). I know from experience how tempting it is to fall into excessive "dialogue" - becoming simply two characters speaking to each other, rather than a narrator describing their conversation. This difference is vital, because to shut the audience out of the story goes against the essential aspects of storytelling, which is an art created through interaction - one cannot tell a story to someone who is not there. This kind of performance is not a presentation, but rather an exchange of information, reactions, and emotions between the teller and the listener.

If the objective of American realism is to show the audience something, let them peek into some other situation, then the storyteller seeks to share something with his or her audience. Through their laughter, booing, or even lack of a response, the audience communicates to the performer how they feel about the material being presented. In return, the storyteller adapts to the situation, giving the crowd more of what they want, skipping things they dislike, or trying something completely different. Through this interaction, storytelling becomes a community- 
centered performance, and this collaboration helps foster a sense of unity between people from all walks of life. It breaks down the notion of a sacred, untouchable canon and instead creates a story that may be taken and shaped by any hand equally, imparting the power not only to the performer telling the story, but to everyone who hears it as well.

As an American actor, the temptation is always present to retreat back into myself and find comfort in something much closer to the realism with which I am familiar. Rather, I must fight to keep contact with my audience, selecting particular people to tell the story to at certain points, or passing through a series of people as I switch between characters or share a reaction or emotion with them (Mitchell 15-6).

The overly expressive pantomime associated with Fo's Mistero Buffo is equally important to his style, utilizing the human imagination to supply every requirement of the story. The storyteller, through vocal quality and gesture, can construct and destroy anything imaginable as necessary, from a barren volcano to an elegant lady's ball gown (Jenkins 246-7). The audience does the hard work by imagining the scene as described, and it is up to the storyteller to support the creation - by not walking straight through a table, keeping consistent placement of the volcano, or just moving as if they were wearing that ball gown - at least until that convention must be discarded to progress through the story. This collaborative process between the performer and audience to imagine the entire visual environment is the most prominent and constant way that the power and authority over the piece is shared between the two parties, in addition to being a way for them to actively reject the need for elaborate elements of spectacle that require a large budget.

I learned this superpower from an Italian student who offered feedback on the performance of my story during the first session of the Fo Project in the summer of 2013. I was 
telling the story of a serf who woke early in the morning, walked to his master's farm and worked all day before walking home again, until one day he gets hopelessly lost on his way home. Without understandable language, the student helped me set this up by creating specific reference points on stage for "home" and "farm" - the serf"s home was in the upper right quadrant of the stage, the master's farm was in the upper left. I pantomimed waking up in the home area, walking to and working in the farm area, and back home to sleep. This cycle was repeated three times until, on the third return home, I destroyed the "home" reference point - I walked to the same spot, but stopped short, looked very confused, and searched the stage and audience for the disappeared "home." That was enough to convey the situation to the audience, even without vocal support to augment the confusion and worry.

A certain characteristic of a story that can make it ideal for storytelling is the number of characters involved in the plot. Because each character must be fully realized - with his or her own physicality and vocal qualities to distinguish him or her for all other characters - if too many characters enter a story, the lines between them may grow messy and make it difficult to differentiate between them. The myths I chose to perform were suitable in this aspect: "Echo and Narcissus" has four major characters and "Orpheus and Eurydice" really only has three. Because I perform these two myths back-to-back, this meant I needed to create seven distinct characters, which is very possible with ample physical and vocal variety.

We were even trained in how these kinds of performances should be constructed: using the given stories from Mistero Buffo, we were assigned to break down the entire story into three large arcs, a beginning, middle, and end. Then from there, we were to break each of those arcs down into three smaller ones, and so on until we had turned the story into a map for the performance to follow, showing us where to ease the audience in with rising action, build the 
energy, ramping up, until we spring into the next part of the story and change gears for beginning a new arc. These are tools commonly used by playwrights in drafting their scripts, but instead I applied them through my body in action, rather than words on a page.

For example, in the above referenced section of my story, the journey from the everyday routine of the serf working on the farm to his getting lost was one of my smaller arcs. I set this section up by running through the entire process step by step: "I woke up, even before the sun came up, and walked all the way to my master's farm, where I worked... and worked... and worked! I worked all day long, while the sun crossed the sky and set in the west. Then I had to walk all the way back home, dragging my aching feet, where I fell down into bed, fast asleep... Until the next morning!" Having set up this routine, I "woke up" and ran through it all again, but just a little faster. The next time, I went even faster, but still kept everything exactly the same, to emphasize the monotonous existence of such a laborer. The third round I didn't even have time to vocally explain everything I did, just sputtered words in a constant stream until I suddenly froze before looking around frantically for my lost home. The increases in speed helped ramp up the action and intensity of the arc until I had the momentum to propel myself into the next part of the story.

This intellectual technique for dissecting a story into its arcs, useful for understanding how Fo's stories are set up to be performed, has been invaluable for me in creating my own piece - I have applied the arc structure to the myths and have found where they fit and where they need to be altered to make a more cohesive performance. For example, early in "Orpheus and Eurydice," Eurydice is taking a break from her wedding festivities when she is bitten by a venomous snake. She falls to the ground, which Orpheus sees, causing him to run to her as fast as he can, but she dies before he can even reach her. The first time I told this part of the plot, 
which served to end the first major arc of the story, it was very quiet and sad, with a distinct lack of energy. I had decided that this was a tragic moment, and told it accordingly. However, as I physically marked though the myth on my feet from the beginning to this point, I realized based on the speed and effort that my body was exerting at this point that I was not putting enough energy into the segment to leap into the next part of the plot. This was causing the story to become too slow and stagnate right at the beginning.

After discovering this, I wrote in my performance notes, "Don't let it die! Ramp it up!!! THIS IS URGENT!!" This led to the way I currently perform that scene, as an epic race against time, with Orpheus dropping his lyre and rushing to Eurydice's side in a panic.... only to find her dead already. This discovery causes a shift, dropping the energy of the performance from its heightened state into a lower, introductory level as I begin the next arc of the story. Then, if the audience is responding to the tragedy, I can indulge them by emphasizing Orpheus' grief and mourning before continuing the story. But I must have ramped up into the next part of the story in order to make such an indulgence.

This is something we were taught as an important element of Fo's style of storytelling: the mixture of comedy and tragedy. The pieces performed in Fo's solo show, the Mistero Buffo (literally, "comical mystery") stories, are all tragedies, and yet in watching him perform, the audience laughs throughout these tragic tales. If I tell the story sadly from the beginning, because I know Eurydice will die, the audience would lose interest because of the monotony of such a telling. I must offer them high and low points, moments of excitement and despair, of comedy and tragedy, to keep them engaged and contributing to the piece.

These are techniques that the giullari would use to hold their audience's attention. This was even more vital for the giullari than for modern performers, the ability to convince a crowd 
to pause in the town square and watch their show was the difference between life and death. These techniques have been developed and refined over centuries to keep the audience invested in the story being told. Fo's inspiration from the giullari was likely boosted by his political leanings - he saw the jesters as champions of the common people who mocked the cruel nobility and gave joy and hope to a usually desolate group of people (Mistero Buffo 17-8). These ideas are present in his works - comedic pieces that have political implications favoring the lower class.

Fo's work serves to help actors realize their own potential, placing the power in their hands to rebel against the restrictive standards set in the typical American rehearsal room. These are the same tools available to me, a young actor lacking the resources required to put on a full scale production in American realism. Fo's work, simultaneously innovative and ancient, has given me the power to rebel against the restrictive labeling of what is and is not considered theatre from the American viewpoint, and granted me a sense of creative ownership over my own work that was disappointingly absent in almost all of my previous theatrical endeavors.

But more than that, it helped me enter a forum in which I could begin a meaningful dialogue with a community. The omnipresent fourth wall in American realism behaved as just that, it placed a wall between the performers and audience, dividing a community and giving one a position of power over the other, which resulted in circumstances which shut down the audience's possibility for input. Now when addressing a problem, instead of repeating a writer's opinion of "this is how you should fix this," I have a place to personally ask "how can we fix this together?" This is the kind of environment of actor-audience interaction that I am interested in exploring with my work, and the Fo-style storytelling served as the vehicle of my arrival into this type of exploration that is so far removed from the majority of my theatrical training. 


\section{Chapter Two: Mythic Storytelling}

What I find very appealing about working with ancient Greek myths is their universality and accessibility - these are stories that have survived for thousands of years, largely because of those two qualities. These are tales that people across cultures can relate to: stories of revenge, lust, doubt, vanity, jealousy, etc. These are the aspects of human nature that relate to all people, no matter how far apart they may be in time or geography.

But beyond that, these are stories that are totally open for use by the public. Too old for the issue of copyright to come into play, these myths can be taken, adapted, and transformed by anyone with the inclination to do so. The stories themselves are living, growing and changing with time, and are thus held in a sort of collective ownership by the human race - Orpheus and Eurydice's story, or Echo and Narcissus', does not belong to me any more than anyone else. This alone serves to smash the hierarchy of power established in American realism: because there is no playwright, no intellectual property, and therefore no set of intentions or ideas that must be respected, the societal microcosm is deprived of its god-figure, opening up the opportunity for more freedom for the performers.

From oral stories to written anthologies, plays to movies and cartoons to comics, the ancient Greeks myths have been reinterpreted countless times for more than 2000 years. While both of the myths I perform appear in their classic forms in the Roman poet Ovid's Metamorphoses, both have served as inspiration for artists across centuries. "Orpheus and Eurydice" is a particularly popular myth, having been reimagined and adapted by many famous artists, from Jacopo Peri's 1600 opera Euridice to Jean Cocteau's 1950 film Orphée, to Sarah Ruhl's 2003 play Eurydice. Likewise, "Echo and Narcissus” was particularly inspiring to visual artists, and were immortalized in Francesco Xanto Avelli's 1535 maiolica, Echo, Amor en 
Narcissus, and John William Waterhouse's 1903 painting, Echo and Narcissus, before Narcissus was featured in an interlude of Mary Zimmerman's Metamorphoses in 1996. And while each adaptation may introduce new elements or gloss over some parts of the stories, certain key aspects of the plots are always present.

The myth "Orpheus and Eurydice" focuses on Orpheus, the mortal son of the muse Calliope. The muses, goddesses of the arts and sciences, passed their talents down to Orpheus, who was exceptionally skilled in music. He played the lyre and sang so beautifully that wild animals would rest calmly by his feet and even trees would bend closer to listen.

Orpheus was in love with a beautiful girl named Eurydice, but on their wedding day she was bitten and killed by a venomous snake. Filled with grief, Orpheus could not live without her and decided he must retrieve her from the underworld at all costs. He traveled where no mortal should ever go, but was able to bypass all of the guards - the ferryman, Charon, and the giant three-headed dog, Cerberus - by singing. When he finally reached Hades, the king of the underworld, who was ready to refuse Orpheus' request, he sang a song so beautifully sad that Hades wept tears of ice and agreed to return Eurydice on one condition: Orpheus must not look back at her until they reach the sunlight in the world of the living.

Orpheus was overjoyed and set off to return, hearing the soft patter of footsteps behind him. But on the journey, his doubts began to grow. He worried that Hades was playing a trick on him, or if it was even Eurydice following him. As the sunlight came into view, he was unable to hold back his paranoia, and turned around, just in time to see Eurydice before her spirit vanished, lost forever. Orpheus was inconsolable, and eventually committed suicide by throwing himself into a river. His body floated on while his soul drifted down to the underworld to finally be 
reunited with Eurydice. The muses, in mourning, plucked up his lyre and hung it in the sky as a constellation (d'Aulaire 100-4).

The story of "Echo and Narcissus" begins as so many do, with Zeus, king of the gods, having extramarital liaisons with attractive young women. Hera, his wife and queen, was jealous as always and was hunting him down, when a young nymph named Echo showed up. Echo loved to talk, and her constant chatter distracted Hera long enough for Zeus to escape. Enraged, Hera curses Echo by taking away her voice and making her only able to repeat the words of others (an explanation for the aural phenomenon for which Echo is named).

We are then introduced to Narcissus, a very handsome but very vain hunter who spurned the advances of any woman who fell in love with him. Echo was one such woman, but she was unable to speak to him, so she merely follows him around, hoping to hear some affectionate words she could repeat to him, until he spurned her as well. Echo lost the will to live and wasted away, until all that was left was her voice, which goes on repeating the words of others, even today. Eventually, Narcissus saw his own reflection in a pool of water and fell in love with himself, becoming completely obsessed with his own image, unable to look away, until he similarly faded and died by the water. Like Echo's voice, Narcissus' beauty is preserved by transforming him into the narcissus flower (d'Aulaire 92).

These particular myths appealed to me for several reasons. For one, I drew inspiration not only from my research on Fo and my training during the Project, but also my own personal interest. In my youth, I was an avid reader of ancient Greek myths; those stories shaped a good deal of my childhood. Besides their strong relation to my artistic interests, they were two of the ones I grew up reading in my big illustrated book of Greek myths. Looking at how Fo used his Catholic upbringing to influence his own work, creating original pieces from apocryphal tales 
(Mistero Buffo), I decided to follow his example and take stories I grew up with and adapt them from written texts to live performances. These two myths have been envisioned and produced countless time over millennia through poetry, paintings, and dramatic works, but my performance of them is different from any other version because they are so specific to my personal readings of these ancient stories - I emphasize different sections and even reorder certain events from the classical versions.

The second reason was that, both structurally and content-wise, these myths meshed very well with the work I'd done in Italy on the Mistero Buffo stories. There were several clearly defined characters but not too many that would overload the stories' dramatic arcs of rising action and climax occur several times throughout each myth, and there are many opportunities for comedy despite being tragic stories. All three of those aspects made the adaptation of these myths into Fo-style storytelling relatively easy, as the natural parallels already existed.

I tell the story of "Orpheus and Eurydice" in English, and then follow with "Echo and Narcissus" in grammelot. As explained by Bottini, a grammelot is a made up language that features gibberish words, onomatopoeic sounds, and just enough understandable words to make sure the audience comprehends the whole story. Grammelot can resemble other languages in their sounds, tonality and phrasing; thus one may perform a nasal French grammelot, or a guttural Russian one.

This practice of using familiar sounds without any logical meaning is one way that traveling Italian troupes in the $16^{\text {th }}$ century were able to perform for international audiences and be understood (Mitchell 12), and was developed by Ruzzante Beolco, whom Fo considers the true father of Commedia dell'Arte (“Against Jesters”). Not only does this removal of understandable language resonate with Echo's plight in the plot of her myth, it also introduces a 
realistic situation in which the body of an actor becomes more important than a playwright's words - without a translator or interpreter available to make a play understood, all the playwright's words become meaningless when performed for a different audience than intended. Conversely, a performer creating a story physically, through his or her body, can facilitate a conversation with anyone of any culture through their art.

I chose the performance style for each myth based on my artistic interest in each. During "Orpheus and Eurydice," I act as the Orphic deliverer, telling a cautionary tale devised by the ancient Greeks, demonstrating the consequences of doubt and impatience in order to extol the virtues of patience and faith to my audience. Then, during "Echo and Narcissus," I strip myself any common language with my audience and have to make them understand me despite this impediment through the specific storytelling techniques in which I was trained by Bottini.

\section{Myth Off the Page}

Despite how well suited these myths are to Fo's style, I could have chosen to perform them closer to the Stanislavski base in which I was trained. I could have adapted these stories into script-format, held auditions and presented these two myths as short plays. This has been done fairly recently for these myths, in 1996 with Mary Zimmerman's Metamorphoses and then in 2003 with Sarah Ruhl's Eurydice.

Metamorphoses is a collection of transformation-themed myths, based off the classical poem by Ovid of the same name. It presents both narrators who set up and describe the myths and actors who perform them, and includes the stories of "Orpheus and Eurydice," as well as an interlude that features Narcissus' enchantment by his own reflection in the pool of water that dominated the stage (Zimmerman 48). 
Ruhl's script, on the other hand, focuses entirely on the myth of "Orpheus and Eurydice", but told from the latter's perspective. The story is updated to an abstractly modern time before descending to the fantastic underworld where a trio of talking stones serves as the chorus of this Greek tale. Ruhl introduces new characters, including Eurydice's dead father whom she encounters in the underworld, which can only be entered into through a large raining elevator. The most drastic change, however, is Eurydice's conscious choice to make Orpheus look at her, allowing her to stay with her father (Ruhl 60).

These scripts, though tweaked and adapted, successfully retell these ancient Greek myths through ensemble-based action. As is necessary with these magical stories, realism is abandoned, and the narrators in Metamorphoses actively break the fourth wall, just as in Fo's style.

Following their example, I could have done something similar, written my own play, despite my lack of skill in that area, to address the issues that interested me. This would have been much more familiar given my education - it is not at all near Stanisklavski-level realism, but the grounding in a written text is something with which I knew I could work comfortably.

However, this would have just been continuing the grim cycle in which the oppressed become the new generation of oppressors. Morally, I could not assert my own artistic perspective while suppressing others' ability to do the same. If I had tried to be the considerate playwright/director and permitted my actors to use their own artistic license in their performance, that would have compromised my own vision - I would have still been the powerless party, despite being in the more powerful role. Additionally, I would not be in the space to interact with the audience myself - I could have written the script in such a way as to allow my actors to respond to audience input, but I would not be a part of it. In this situation, I would be the 
playwright, the god-figure of the production, removed from the happenings in both the rehearsal room and the stage, removed from involvement with the community as a whole.

Or I could have made use of a process I had explored previously: during the 2011-2012 school year I was part of a project focused on ensemble performance and community-based arts. During the fall semester, I was enrolled in a class in which we interviewed members of a chosen community - we focused on athletes and sports fans - and as an ensemble, wrote a play based on information from the interviews, which we later performed as part of the mainstage season in spring 2012, PLAYS: A Play. However, taking this approach would still produce a script that would need to be respected, careless improvisation could throw off some technical elements or other actors, so the performance would need to stay relatively static, leaving little opportunity for audience input to affect the performance, denying them a manner to join the conversation Instead, my work on the Fo Project made available to me the option to examine how a solo storytelling adaptation, completely unique to me, would be different from those kinds of plays, especially coming from a background dominated by America's text- and ensemble-based performance. This showed itself to be the best option available; allowing me to control my work, without limiting anyone else's, and engage with the audience personally. 


\section{Chapter Three: To the Underworld}

In developing my story versions of these two myths, I followed the process through which Bottini led us during our first summer of work - during which we rehearsed and performed our own versions of certain stories from Fo's Mistero Buffo. Most of the participants in that program, myself included, were not more familiar with the material than having read the story once or twice. Together under Bottini's instruction, we developed our own versions of our chosen stories simply by telling them and discovering what worked well in the moment.

My interpretation of Orpheus' descent to the underworld is told differently and, as a result, has a different meaning from other versions of this classic myth. In Zimmerman's Metamorphoses, the narrator who introduces the story simply says that Orpheus "dared to descend to the river Styx and crossed it to the Underworld," skipping over the trip entirely (41). And in Ruhl's Eurydice, Orpheus' journey is similarly glossed over, in one scene, he describes his abstract plan to reach the Eurydice - by falling asleep with a straw in his mouth, crawling through the straw once asleep, and singing a certain note to find her - and in his next scene executes the plan before appearing at the gates of the underworld (52-4).

But in my piece, the content of the myth is strongly connected to the style in which I perform it. Orpheus is defying the natural order of life and death in his descent to the underworld in the same way that I am rebelling against the mainstream power structure of American theatre by taking on the role of an actor-creator, using my body as the creative instrument, and sharing artistic authority with my audiences. This led to emphasis being placed on Orpheus' transgression against the laws of the gods; his trip down is the longest and most significant section in my telling of the story, and he faces challenges and trials along the journey to highlight the gravity of both his and my decisions to rebel. 
Then, once Orpheus has reached his destination, he must plead with Hades to release Eurydice. The god is initially intent on refusing, until Orpheus sings the most heart-breakingly sad song, that Hades weeps tears of ice that freeze upon his cheeks, and obliges Orpheus' request. This is the way he successfully persuades the god of the dead in the version of this myth with which I grew up. However, this plot point is open to interpretation by other artists, some of whom have taken the opportunity to alter the interaction of these two characters. In Ruhl's version, for example, the Lord of the Underworld is not impressed at all with Orpheus' singing. He knows immediately that Orpheus has come for Eurydice, and just tells him to walk back the way he came and that Eurydice would be following him (56-7). And in Zimmerman's play, Orpheus simply kneels before Hades and has some very eloquent lines which are enough to convince the god of the dead, he doesn't sing at all (42).

I, on the other hand, chose to keep Orpheus' method of convincing Hades because it demonstrates the power that an artist can hold alone, performing his or her own original work. A solo artist in Orpheus' situation is able to match the almighty power of a god - or a playwright, in my analogy - through their art alone. Now it is important to note that theatre is the only art form where it is considered odd by mainstream standards for an artist to create his or her own work: a painter may choose what to paint, a writer what to write, musicians may compose their own music, and even dancers can choreograph their own movements. The plot of the myth shows the great things that artists can do, and my performance style highlights the struggle to elevate actors to the same level as other artists in their creative capacity. But the actor can also extend the creative capabilities to his or her audience due to the direct contact that may be established between these two parties. This can bolster both entities, so that it is not an artist alone facing the perils of hell; it is a community working together as an artistic entity. 
Artists and audience alike are allowed to fully explore these powers of creation due to the semi-improvised nature of this work. In Fo's style, five people could tell the same story, hitting all the same plot points, but the actual telling can be drastically different depending on the performer. Each different storyteller brings their own particular skill set to make each performance unique. If the performer was very skilled in grammelot, or had mime experience, their story would have its own unique flavor to set it apart from other versions of the same story. Even physical appearance could be utilized - for example, one woman was particularly short and her story included a confrontation with a short person, she used her height to make this moment even funnier than in the original by showing through gesture that this short person was even tinier than her, placing them around the size of a baby, before fighting with them.

I used this same process to create my performances of the myths. As I was familiar with the stories before beginning work on this project, I began by just telling them and seeing what came out of it. The strong points of my skill set for this type of work are my thoroughly developed grammelot (influenced by a mixture of the Italian and Spanish languages), and my wide vocal range, so after one or two times in English, I switched to working both in grammelot to further develop them.

Even though I eventually performed "Orpheus and Eurydice” in English, rehearsing it in grammelot is a very useful tool to discover new things in performance - for instance, I found that as Orpheus sings his way past the guards of the underworld, each one weeps and sinks a little lower to the ground, until Hades himself is so overcome that he almost falls to the ground. This also helped me avoid the trap of becoming a static narrator instead of a dynamic storyteller. When speaking a common language with the audience, it can be easy to fall into simply speaking the story to them. But what makes Fo's style so fun to watch is the full-body engagement of the 
storyteller who is physically as well as vocally describing the story. Practicing this myth in grammelot has helped me develop a physical storyline to run concurrently with my spoken one so that I don't end up standing still on stage and talking. This was vital, as my process of using the body as a creative force would be worth nothing if I did not continue to use it as such during my communications with an actual audience, in order to enhance my contribution to our exchange of information.

I also faced challenges from the myth itself. I was naturally able to see comic moments in "Echo and Narcissus," but they were tougher to spot in "Orpheus and Eurydice." My impression of this myth is more tragic, and that affected my method of adapting the myth to Fo's style. In the end, I decided that was all right - I would include comical moments where and when they arose organically and not worry about making this piece into a comedy. I really like to make people laugh and tragedy is not the genre I usually live in, but it is the genre that spoke to me for this particular piece, and I felt it would be a disservice to my work if I ignored that instinct, especially at the price of forcing fake invented jokes into an already beautiful story.

Several funny parts did crop up in rehearsals, such as my construction of Cerberus, the monstrous three-headed dog that guards the gate to the Underworld. This is a strong image that I wanted to emphasize by having the hellhound appear on stage for the audience. Lacking such a dog, I became him, describing the scene with one mouth as my hands rose up by my head to become two others, just before all three begin to bark in an angry cacophony, before they are all soothed into submission by Orpheus' music.

This was an important moment, not only for the image it created, but in how it served the structure of my piece as a whole. In crafting this piece, I needed to carefully introduce my audience to the conventions of the performance and give them time to adjust accordingly. 
Perhaps if I was performing this for an Italian audience it would have been different, but going into a room with a crowd of people, at least some of whom had no experience with any style of theatre but American realism, required a deft touch. If I had marched up center stage and begun barking with my hands, many people in the audience may have shut down instantly and let their minds wander from that point on.

This is part of the reason why I begin my performance with a prologue. This is a habit I picked up from the Fo Project - before we performed our stories in Italy, we were instructed to explain to the audience, briefly, what they would be seeing and why we felt it important enough to show them. I use this method to prep my audience for a style of theatre with which many will be completely unfamiliar, letting them know to open themselves to a new experience.

This is also the reason I ordered the myths the way I did. Again, placing my audience's needs and understanding at the top of my priorities, I decided to introduce them to this new style slowly. "Orpheus and Eurydice" opens calmly; I will simply be telling them the story, but throughout, the same way I ramp up to proceed into new arcs of the story, I will build the performance into the more physically dynamic style that will be in full effect during "Echo and Narcissus." Telling this first myth in English serves the same purpose - by the end, the audience will be more comfortable with the performance style and will still be able to keep up when I take away understandable language and follow the story.

This is my main concern in producing this project, to empower the actor, as an artist, to communicate directly with his or her audience freely, unencumbered by the interference of playwrights or directors or excessive technical elements. An inextricable element of that goal is to make sure the audience understands the message being sent, so that an open exchange between the two parties can occur through the performance. 


\section{Chapter Four: Finding a Voice}

My rehearsals of "Echo and Narcissus" really let me engage my creativity as I reordered the story. In my version of the original myth from my childhood storybook, Echo dies of grief after Narcissus jilts her, who then goes on to see himself in the pool of water and become enchanted. I was dissatisfied with this ordering of the story - Echo opens the story, but drops out before the climax. In adapting this classical myth to a modern performance piece, I made the decision to change the sequence of certain events. In my version, after having her affections spurned, Echo continues to follow Narcissus and watches him slowly waste away and die by the water. It is then her who changes him into the narcissus flower before fading away. This version is, in my opinion, more emotionally charged and cohesive than the original version.

I was not initially sure I wanted to alter my original text to that extent, but ultimately concluded that this creative decision would make much more sense to me dramatically. Beyond that, I was inspired by Fo's irreverence for authority on this matter. He is not an artist who is bound by rules, tradition, or facts. This is clearly evidenced in his reinvention of classic Biblical tales, such as the Resurrection of Lazarus (Mistero Buffo 97-103) or the Marriage at Cana (Mistero Buffo 105-13). His indomitable drive to preserve the authenticity of his work persisted even to the point of making an enemy of one of the most powerful institutions in the world, the Catholic Church. This aroused a similar fire in me to truly assert the power I had accepted by initiating this project, to reaffirm that this artistic endeavor was mine and under my control, and that I could proceed however I chose.

Here, it was my choice to include Echo at all that set my adaptation of this myth apart from others. Zimmerman includes a "Narcissus Interlude" in Metamorphoses as a silent transition piece in which a male actor stares into the pool of water on stage, transfixed, until he is 
carried off and replaced with a potted narcissus flower, but Echo never makes an appearance (48). The nymph is most prominently featured in visual art, such as Waterhouse's "Echo and Narcissus," but even in her visual depictions, she is depicted as seated and gazing longingly at Narcissus, never doing anything active. Her voice is taken away by Hera in the myth, but she is continually deprived of it by her exclusion from theatrical adaptations of her story and being relegated to exist only in visual art.

This is the same tragic disregard that afflicts actors today in mainstream American theatre; their voices are taken away in favor of the playwright's words, which they are forced to repeat over and over again with little input of their own. My adaptation, however, lets Echo defy her punishment. The loss of her voice should have effectively ended all control she had over her own existence, but I grant her the power to choose her own fate. After Echo uses her own power to transform Narcissus into a flower, she sits by it at the side of the pool and stays there, day after day, until her body fades away and only her voice is left. My version lets her control the ending of her own story. In the same way, I as an actor am finally taking control; revolting against a system that has stolen the voice of both the actor and the audience, and letting us both work as creative entities to share authority over a work of art.

In the midst of struggling with this choice, I was fortunate enough to be enrolled in Graduate Movement III. I started the Graduate Movement track in the University's Theatre Arts department the semester after my first summer with the Fo Project, through which I have been exposed to many non-realism based theatrical styles, such as the work of Rudolph Laban and Commedia dell'Arte. A majority of Graduate Movement III was dedicated to training in Fo-style storytelling, but as I had already received a very strong base in Italy, I was able to instead work on one of the myths for my project. 
As I would be performing for a group of classmates who had no real experience with Fo's work, I decided to work on "Echo and Narcissus." Because this is the myth I tell in grammelot, I wanted to make sure that audience members with no knowledge of theatre would be able to understand my story. Workshopping my story and getting feedback from my classmates and instructor was invaluable and greatly accelerated the progression of this myth, leaving me more time to cultivate "Orpheus and Eurydice."

My first showing of "Echo and Narcissus" was very short. I did not include as many details, but I also rushed through a lot of it. This was probably caused by a psychological effect during the first year of the Fo Project, the story I chose to tell was "The Birth of the Giullare," a story by Fo that is incredibly long and riddled with details, telling it could easily take 30 minutes. Because the last story I worked on required brevity, I applied that same rush to "Echo and Narcissus" when it was unnecessary. As a result, most notes were about making things clearer for the audience - Why was Hera angry at Zeus, was Narcissus a hunter or a warrior, etc? Additionally, I fell into my habit of wanting to be funny for my audience, and my first draft was a total farce, I highlighted Narcissus' death by shrugging and saying, "he died.” That got a laugh, but part of what makes Fo's work so captivating is his masterful integration of comedy and tragedy.

Working through the storyline in an intellectual way through the use of my body gave me a preview of the story in action as it was still being created. This was invaluable, especially for me personally, because it allowed me to see immediately if a new addition was working or not. A problem I encountered when I had previously tried to write plays was making decisions about plot and structure because they made sense to me internally. Developing this piece with my body, rather than words, let me explore the story as it would actually be performed, which made 
it apparent when a decision I had made needed to be revised - if I was not incorporating full body engagement, especially in this grammelot piece, I needed to make a different choice to involve my body as a creative instrument.

For example, while revising my performance after audience feedback, in my initial effort to show Narcissus more clearly as a hunter, I had Echo watching him as he tracked some deer through the forest, at which point Echo would fall in love with him. However, this proved to be underwhelming when I began to rehearse this section on my feet. Tracking a deer was very inactive, and consisted of Narcissus looking at the ground and running off while Echo observed. I realized that Narcissus, for his introduction as both a hunter, and as the object of Echo's affections, needed to have a huge entrance with fanfare and heroism. I figured out that he needed to be actively killing something as a hunter, and something bigger and more dangerous than a doe. As these new circumstances entered my head I began moving physically through the story up until that point, to Echo's banishment from Mount Olympus, where Hera cursed her, to Earth.

There it all clicked into place. Echo's physical mood changed from curiosity to fear as she explored this strange new world, until she eventually encountered a large monster. She turned and ran as the monster, or "rawr rawr!" in my grammelot, chased her through the trees until she collapses, exhausted at the mercy of the beast. But just before it went to devour her, I cut away from this scene to an archer nocking an arrow, aiming, and firing. The scene shifted back to the monster, as the arrow caught it in the shoulder, saving Echo at the last minute. She scrambled away and hid as Narcissus entered the scene, sword held high, killing the monster. Then, three more monsters came at him as he fended them all off - and each time one was slain, there was a cut to Echo whose heart gave a "thump thump" as she leaned closer and closer to 
watch the action. When this fight ended, Narcissus' reputation as a hunter and manly man was clearly established, as was Echo's overwhelming infatuation with him.

Another major aspect that I was able to develop through rehearsal was the differentiation between characters. As I told this myth in grammelot, I could not hope that my audience would be able to follow the shifting between characters without an understandable explanation of "He said... then she said..." So, I had to create very specific characterizations to make it clear which character was speaking at which time.

Interestingly enough, as Hera and Zeus are only in the plot for a short time and because the audience only sees one side of the character, the two gods are less complex and important in this myth than the other characters; I did not have to go into great detail creating them. Hera is angry the entire time she is on stage, so her voice was loud and furious, while I kept her arms down toward the ground with fingers splayed, imagining horrific claws for attacking her philandering husband.

For Zeus, it was simple enough to make a pulling gesture down from my chin to indicate a beard that defined his character. But in order to make Zeus' personality, in addition to his appearance, clear to the audience, I set Zeus' space each time by creating six large-breasted women crowded together, before placing Zeus right in the middle of them. This not only got a laugh from the audience each time, but it made Zeus' character easily identifiable - not only in the story, but gave him a recognizable type of person who could be found in the real world. This was my way of deflating the religious reverence associated with this god-character, by humanizing him and taking away the inscrutable power inherent in godhood.

Differentiating Echo and Narcissus was more challenging, and vastly more important. These two characters are not only present during most of the story, but their extended 
interactions with each other meant they had to be visually and audibly distinct, or else the audience may grow confused about who was saying what and when. Echo's voice, as she is a female nymph, went higher and more into my nasal register, giving her a squeaky tone.

However, as she loses the ability to speak early in the myth, her physical difference needed to be significant, but not overpowering. In the end, it was as simple as having one heel off the ground, balancing with the ball of that foot. This tiny adjustment caused my weight to shift into my other foot and one hip stuck out, changing the shape of my entire body to make Echo her own distinct character.

Narcissus, however, was primarily a vocal change. If Zeus turned into the archetype of the lecherous old man, Narcissus became a dumb jock. I set my voice much lower than normal, to a point where it sounded both pretentious and incredibly dim-witted. Complementing this with arms that constantly try to curl and flex to show off muscles added an extra detail that cemented him as a character in my mind, and the audience's.

For my second showing in class, I took a breath and let myself enjoy telling the story, rather than rushing through it and without the need to make my audience laugh at every line. I set up Zeus' philandering, made Echo enrage Hera to the point of bursting, added in a new sequence where Narcissus kills a bear that was chasing Echo, really showed just how much Echo loved him, and made their deaths heartbreaking and tragic. The alterations paid off and my audience had a much clearer understanding of the story itself. This opened up room for them to give me more feedback, as well as comment on the story itself afterwards - but they also communicated with me during the performance.

As Echo delayed Hera with her chatter, Hera became frustrated and let out a loud scream of rage. While continuing to hold this yell, I used my index finger to point to my vocal chords 
and then make a gesture of something coming out of my mouth. This immediately indicated to the audience that my finger now represented the sound waves of my continued scream. While still holding the note, I pointed to the spot where I had previously set up Zeus and his gaggle of women, ran there and repeated my set up of all the women with Zeus in the middle. Them my index finger came back as the sound waves, snaking through the air until they slipped right into Zeus' ear. My audience was giggling throughout this entire sequence.

Because they clearly enjoyed that segment of the story, I decided to include another one later. After Zeus had escaped Hera's wrath and she cursed Echo, Hera snapped her fingers, opening up the clouds around Mount Olympus and sending Echo shooting downward toward Earth. As this point, Echo has lost her voice and cannot even scream. Instead, I kept my mouth open and put energy into my face to look like I was screaming, just without making any sound. After a few frightened gestures, my right hand shot up above my head, with my index and middle fingers extended pointing down to look like legs and moved downward slowly. Then with my other hand, I pointed to myself, then to my right hands, all while "screaming," making it clear that my hand represented Echo falling through the sky. Once this realization hit, my audience started laughing again and continued until my right hand got near my hips, at which point I jumped in the air and landed saying, "Boom! Earth."

Had my audience not responded to my first use of these storytelling conventions, which allow my body to become sound waves, or my hand to be my own body on a smaller scale, I would not have made use of this convention a second time and instead streamlined the moment of Echo's fall. However, because the audience was able to give me direct feedback on their enjoyment of the piece, I was able to adjust the parts that followed to appeal to them. This made 
my performance of "Echo and Narcissus" not just my own piece, but one that was communally devised in the moment. 


\section{Chapter Five: Creation}

The three-night run of my show was my opportunity to put into practice the concept of sharing creative authority with the audience. I had had some audience participation in my crafting of "Echo and Narcissus," but the majority of my piece was physically devised by me alone. However, once I had created the basic structure of the story, it would be up to each night's audience to communicate with me, to decide how the performance would be changed from show to show.

The set up for my show was incredibly simple as I continued to be inspired by Fo's conventions. My stage was bare and I was dressed only in a plain white button up and a pair of black pants that allowed me a wide range of movement - I rejected the elaborate elements of theatre that would have required great sums of money to fabricate, and instead relied on my body to create any scenery, costumes, or props I needed - such as showing the twisted gates of the underworld with my fingers, or becoming a giant three-headed dog using my hands as the other two heads.

The only technical element I did include in my performance was the most necessary: lights. However, I not only had to make sure that my audience would be able to see me; I had to be able to see them as well. I ensured this by keeping the house lights, the lights that illuminate the audience seating in the theatre, on as I performed. In most mainstream American theatre, in which the audience is an unacknowledged observer, the house lights would go completely out when the show began, and the bright stage lights would make it all but impossible for the actors to make out their audience under most circumstances. By only dimming the house lights slightly at the top of the show, I was still able to make out my audience members and make eye contact with them, allowing us to connect and share the story together. 
The first night I had a very small crowd, only four people in the theatre. This caused me, I noticed during the performance, to spend a good deal of time downstage, closer to my audience than I did on other nights with larger crowds. The small number of people created a more intimate setting for my piece that allowed me to connect more with each person. As I could only switch between telling the story to four different people, I got to spend more time with each of them, sharing the story with them specifically. This let me take into account each person's input into the story more than I usually would have been able to. If a person laughed at certain parts, I would be sure to direct similar parts of the story to them again. One woman immediately smiled every time I made eye contact with her to say anything. Noticing all these different factors allowed me to tailor the night's performance specifically for each audience member.

On this night, I encountered my first surprise. Despite all the times over the years I have performed in the Thrust theatre, I had forgotten that it was directly next to a railroad crossing. So, as I was telling "Echo and Narcissus" and a train's horn blew, the surprise of it, combined with opening night jitters, resulted in my turning toward the sound and yelling at the train in grammelot for a second before turning back to my audience and expressing my frustration physically, with my hands on my hips and a sour expression. The audience enjoyed this part and laughed a bit, and I continued the story once the train had passed without a hitch. This kind of response on my part would have been impossible in a realism based piece, and served to show the audience that we were experiencing the story, and all distractions from it, together in the moment.

A similar interruption occurred during my second performance, this time in the form of a text message alert. Again, I was caught unprepared, but knew I must acknowledge the sound as this one came directly from my audience; to ignore it would set a dangerous precedent where I 
might ignore any information given by my audience that I did not like. This time, I again broke out of the story, asking in a frightened voice, "What was that noise? Did you hear that?" then pausing for a moment before cautiously continuing my story. Then, when the phone went off again, I repeated this tactic, stopping midsentence to say “There it as again! ...I think it's okay now," before continuing. This again got a few small giggles, but I realized that in order to truly use my audience's input, allowing us to share total authority over the story, I had to be prepared to incorporate these types of distractions into the story itself.

I was granted the opportunity to do this during my final performance. This evening's surprise was that certain audience members did not feel the need to either find a seat in the theatre, or to remain seated during my performance. As I was telling "Orpheus and Eurydice," I decided it was time to acknowledge these distractions within my story, but I also used this opportunity to test out my audience's attitude regarding the tone of the piece. As I reached the part of my version where Orpheus is visiting with his mother and aunts, the Muses, and telling them of about his grief since Eurydice's death, a young woman stood up and walked right past me out of the theatre. Immediately after she left, I gestured to the exit she'd used, while maintaining eye contact with my audience, and, as Orpheus speaking about Eurydice, said "She's gone..." This got me the biggest laugh of my entire run and informed me that not only did my audience appreciate my incorporation of external events, they were also open to a more humorous rendition of the tragic tale. As a result, I proceeded to play up some of the other comical elements of the story that were already present, such as the Cerberus bit, making that night's show have a unique tone compared to my other two performances.

Whereas my two previous performances of "Orpheus and Eurydice" were more tragic throughout with small bits of comedy sprinkled in, this final night was more upbeat and moved 
faster because of that audience input. This resulted in a much more lighthearted telling, which changed the meaning of the story itself, especially of Orpheus' suicide. In previous tellings, this final act was committed by an Orpheus who was lost, alone, afraid, and overcome with grief, and who felt he had no choice but to kill himself to be with Eurydice. But the final night, after relating the story in a more lighthearted way, Orpheus' attitude at the climax was different. Playing up the comic bits for that audience had affected my own mood when telling this part of the story and produced a scene with an Orpheus who had accepted his own end. I used similar words and actions as I had previously, but the difference was in how I spoke them.

Orpheus' thought process that I shared with the audience was "What can I do now? My life only ever made sense when I was with Eurydice... Well, if I can't bring her back to me, I must go to her." In my final performance, this was not a hasty grief-stricken decision; it was a revelation that dawned on Orpheus, making him realize what course of action he had to take. Before, Orpheus had been consigned to death as a matter of course. But that time, he had finally taken power over his own fate into his hands and chosen to kill himself, the same way Echo took hold of her own fate in her story and how I, as an artist, am empowering myself and my audience to create our own art together. 


\section{Conclusion}

Performing is my greatest passion and the most blissful joy I have experienced, and I could no more abandon it than give up breathing. But I have a brain too; I am not just a machine, a body that will labor under a master's whip in service to an idea that means nothing to me. Through Dario Fo's storytelling style, I discovered new ways to approach performance that gave me an escape from being always trapped in the powerless position imposed on actors by American theatre's mainstream power structure. I wanted to have the opportunity to let the audience hear my voice, speaking my own words, using my art to facilitate communication and understanding. And throughout the piece, I acted as the Orphic deliverer, having ventured into an "underworld," the realm of artistic freedom and opportunity, and returned to share my creative power over the performance with my audience to benefit us both. In a sense, I became a mythic hero, having undergone a trying quest and returned with a boon for the good of my community.

My training with the Fo Project, by empowering my body as a creative entity and establishing direct relationships with audiences, helped me realize my power to take on that kind of role, and made this sort of exploration possible. Without the foundation in this non-text based style of theatre, I may have remained ignorant of my powerless position. Being given a glimpse of a whole new system that could turn the political structure to which I had adapted on its head both made me dissatisfied with always being the tool and gave me hope that I could instead be the artist. I brought that awareness, style, and dissatisfaction back with me to contribute to and influence the power relationships of mainstream American theatre.

I would urge all actors who feel lost, restricted, or passive in their theatrical work to immediately fight back against the forces oppressing them. Whether their interest lie in discovering the potential power within themselves alone, exploring the intellectual and creative 
capabilities of their bodies, or opening means of communication between actor and audience, they will be unable to even test the waters until they gain a reprieve from all the voices that reject even the possibility that they could have any power. Even if this process does not appeal to them, even if they find they prefer being an interpretive, mainstream artist, it would be their choice to be so instead of being forced into that role because it was their only option. Now that I have had the opportunity to empower myself as an artist, though I will continue to perform as an actor in mainstream American theatre, I will not lose the authority to control my own story. 


\section{Bibliography}

Bartow, Arthur. "Introduction.” Training of the American Actor. Ed. Arthur Bartow. New York: Theatre Communications Group, 2006. xi-xl. Print.

Brockett, Oscar G., and Robert Findlay. Century of Innovation: A History of European and American Theatre and Drama Since the Late Nineteenth Century. Second Edition. Boston: Allyn and Bacon, 1991. 426-7. Print.

d'Aulaire, Ingri, and Edgar Parin d'Aulaire. d'Aulaire's Book of Greek Myths. New York: Delacorte Press, 1992. Print.

Fo, Dario. “Against Jesters Who Defame and Insult.” Nobel Banquet. Stockholm City Hall, Stockholm, Sweden. 7 December 1997. Nobel Lecture.

Fo, Dario. Mistero Buffo. Trans. Ron Jenkins. New York: Theatre Communications Group, 2006. Print.

Fo, Dario. We Won't Pay! We Won't Pay! And Other Plays. Trans. Ron Jenkins. New York: Theatre Communications Group, 2000. Print.

Hansberry, Lorraine. A Raisin in the Sun. New York: Vintage, 2004. Print

Jenkins, Ron. "Dario Fo: The roar of the clown.” Acting (Re)Considered. Ed. Phillip B. Zarrilli. New York: Routledge, 1995. 242-50. Print.

Kanter, Jodi. Performing Loss: Rebuilding Community through Theater and Writing. Carbondale : Southern Illinois University, 2007. Print.

Mitchell, Tony. Dario Fo: People’s Court Jester (Updated and Expanded). London: Methuen, 1999. Print.

Mudd, Derek S. “'They accused me of bein' a homosexual': Playing Kerry Cook in The Exonerated." The Politics of American Actor Training. New York: Routledge, 2010. Print. 
Nagy, Gregory. Greek Mythology and Poetics. Ithaca: Cornell University Press, 1992. Print.

Ruhl, Sarah. Eurydice. New York: Samuel French, 2003. Print

Smith, Ashley. "Aerial arial : a lesson in strength and stamina." UofL Libraries Digital Collections. May 2014. University of Louisville Electronic Theses and Dissertations. Web. 25 Jan 2015. 〈http://digital.library.louisville.edu/cdm/ref/collection/etd/id/2947〉

Waterhouse, John William. Echo and Narcissus. 1903. Oil on canvas. Walker Art Gallery, Liverpool.

Zimmerman, Mary. Metamorphoses: a play. Northwestern University Press: Evanston, 2002. Print. 